\title{
Penerapan Latihan Sensorimotor Untuk Meningkatkan Kemampuan Menulis Pada Anak Autistic Spectrum Disorder
}

\author{
Musjafak Assjari dan Eva Siti Sopariah \\ Jurusan PLB FIP UPI Bandung
}

\begin{abstract}
Abstrak: Tujuan penelitian ini dimaksudkan untuk membuktikan bahwa penerapan latihan sensorimotor dapat meningkatkan kemampuan menulis dan hasil menulis pada anak Autistic Spectrum Disorder (ASD). Metode penelitian menggunakan pendekatan kuantitatif, serta dalam intervensi dan analisis data menggunakan metode Single Subject Research (SSR) model Design Multiple Baseline Cross Variable (disain jamak antar variabel) dan disain A - B - A. dengan satuan ukur durasi dan persentase. Hasil penelitian ini menunjukkan bahwa secara nyata subyek penelitian mengalami peningkatan dalam kemampuan menulis. Oleh karena itu, latihan sensorimotor ini dapat dijadikan sebagai acuan dalam meningkatkan atau mengoptimalkan kemampuan vestibular, taktil, kinestetik dan propioseptif yang merupakan keterampilan prasarat menulis yang dimiliki oleh anak Autistic Spectrum Disorder (ASD).
\end{abstract}

Kata kunci: latihan sensorimotor, menuis, dan anak autistic spectrum disorder

\begin{abstract}
The goal of this research is to prove that the application of sensorimotor training can improve writing skills and the writing in Autistic Spectrum Disorder (ASD) children, the research question posed is: Does the application of sensory motor training improve writing skills in Autistic Spectrum Disorder (ASD) children? The method of research applied quantitative approaches, and for the intervention and data analysis, the study used the method of Single Subject Research (SSR) model of Multiple Baseline Design of Variable Cross (plural design between variables) and the design of A - B - A. with a unit of measurement duration and percentage. The results are consistent with the research questions and basic assumptions that the study subjects experienced significant improvement in writing skills. Therefore sensory motor training can be used as a reference in improving or optimizing the ability of vestibular, tactile, kinesthetic and propioseptif which is prasarat writing skills possessed by children Autistic Spectrum Disorder (ASD).
\end{abstract}

Key words: sensorymotor training, writing, and autistic spectrum disorder child

\section{Pendahuluan}

Layanan dan intervensi untuk anak $A S D$ saat ini sedang marak dibicarakan oleh kalangan masyarakat luas. Hal ini karena banyak permasalahan yang muncul dalam diri anak $A S D$ itu sendiri. Mereka mengalami gangguan perkembangan pervasif atau pervasive Developmental Disorders (PDDs-GPP) yang menyebabkan anak mengalami kesulitan berkomunikasi dan berinteraksi sosial dengan orang lain. Ada juga anak $A S D$ yang mengalami gangguan koordinasi motorik seperti keseimbangan, koordinasi mata dan tangan, serta lokomosi. Hal tersebut senada dengan Rarick (1973 dalam Saputra Y, 2005 : 40) yang menyatakan bahwa: anak yang diidentifikasi sebagai autism akan kurang kemampuan geraknya dibanding dengan anak normal sebayanya, diukur dari kemampuan gerak statis dan dinamis, kekuatan, koordinasi, keseimbangan dan kelincahan.

Berdasarkan studi pendahuluan terhadap sorang siswa berinisial AFZ yang tergolong ASD, memiliki karakteristik Memiliki kosa kata yang cukup banyak namun walaupun begitu subjek kurang komunikasi, sering mengulang potongan kata atau lagu dari iklan televisi, menolak adanya perubahan lingkungan dan rutinitas baru, impulsive, cenderung monoton, temper tantrum. Subyek menunjukkan koordinasi motorik yang terganggu, seperti gerakan yang sempoyongan dan lemas ketika lari dan berjalan. Malas-malasan dalam aktivitas menulis, bahkan seringkali enggan menulis karena sering tertinggal dan tulisan yang hampir tak terbaca. Mengalami problem dalam 
melakukan stabilitas kertas pada saat melakukan aktivitas menulis. Kesulitan untuk mempertahankan posisi kepala dan posisi badan untuk tetap tegak (control postural), sehingga tulisan menjadi kurang baik dan kurang bertahan saat melakukan aktivitas. Tangan yang dipakai untuk menulis terlihat ragu-ragu, kurang mantap dan terlihat tegang. Tulisan yang jelek dan hampir tidak terbaca karena bentuk huruf kurang jelas. Memiliki problem yang cukup signifikan pada saat menekan alat tulis di atas kertas dan terkadang melubangi kertas yang dipakai sebagai alas. Pada saat menulis hurufnya kurang jelas terlihat dan ini didapatkan hampir pada seluruh huruf. Serta membutuhkan waktu yang cukup lama untuk menuliskan beberapa kata. Bahkan untuk menuliskan \pm 30 kata subyek memerlukan waktu \pm 20 menit.

Untuk itu perlu adanya suatu upaya yang diharapkan dapat membantu mereka dalam mengatasi permasalahnnya. Salah satunya dengan menerapkan latihan motorik salah satunya latihan sensorimotor. Latihan sensorimotor adalah latihan yang bertujuan untuk meningkatkan kemampuan sensorimotor yang terdiri dari visual, taktil, proprioseptif, vestibuler, auditoris dan kinestetik. Kegiatan-kegiatan pada latihan sensorimotor bertujuan untuk mengoptimalkan proses biologis pada otot dalam mengolah berbagai informasi sensorik dan motorik yang kemudian dipergunakan sebaik-baiknya terutama dalam meningkatkan kemampuan menulis.

Berdasarkan uraian tersebut, penulis tertarik untuk melakukan penelitian sehubungan dengan rendahnya kemampuan menulis yang dimiliki oleh anak Autistic Spectrum Disorder (ASD). Dalam hal ini kemampuan prasarat menulis yaitu kemampuan sensorimotor terutama yaitu: kemampuan visual, taktil, proprioseptif, vestibuler, auditoris, dan kinestetik kurang dipahami sehingga usaha untuk meningkatkan kemampuan menulis menjadi kurang optimal. Penelitian ini menggunakan penerapan sensorimotor yang diharapkan dapat meningkatkan kemampuan motorik khususnya menulis pada anak Autistic Spectrum Disorder (ASD).

Secara khusus masalah-masalah yang dialami subyek dalam penelitian ini sebagai penyebab rendahnya kemampuan menulis subyek antara lain: 1) Malas-malasan dalam aktivitas menulis, bahkan seringkali enggan menulis karena sering tertinggal dan tulisan yang hampir tak terbaca; 2) Mengalami problem dalam melakukan stabilitas kertas pada saat melakukan aktivitas menulis; 3) Kesulitan untuk mempertahankan posisi kepala dan posisi badan untuk tetap tegak (control postural), sehingga tulisan menjadi kurang baik dan kurang bertahan saat melakukan aktivitas; 4) Tangan yang dipakai untuk menulis terlihat ragu-ragu dan kurang mantap. Dengan kata lain, tidak adanya keluwesan pada tangan dan jarijari ketika menggerakkan alat tulis; 5) Tulisan yang jelek dan hampir tidak terbaca karena bentuk huruf kurang jelas; dan 6) Memiliki problem yang cukup signifikan pada saat menekan alat tulis di atas kertas.

Berdasarkan studi pendahuluan tersebut, peneliti membatasi permasalahannya pada keterampilan dasar menulis (visual, taktual, proprioseptif, vestibular, auditoris dan kinestetik) yang mempengaruhi kemampuan menulisnya.

Bertolak pada permasalahan tersebut, peneliti akan memberikan tretmen pada subyek melalui penelitian latihan sensori motor. Dengan demikian tujuan yang ingin dicapai dalam penelitian ini yaitu: mengungkapkan dan membuktikan bahwa penerapan latihan sensorimotor dapat meningkatkan kemampuan menulis pada anak ASD.

\section{Kajian Literatur}

\section{Konsep dasar autistic spectrum disorder, menulis, dan sensorimotor Pengertian Anak Autistic Spectrum Disorder (ASD)}

Kata "autisme" berasal dari bahasa latin yaitu "autos" yang artinya sendiri (menyendiri). Penyandang autisme seakan-akan hidup dalam dunianya sendiri. Istilah Autisme baru diperkenalkan sejak tahun 1943 oleh Leo Kanner. Istilah yang lazim dipakai saat ini oleh para ahli adalah "kelainan spektrum autistik" atau ASD (Autistic Spectrum Disorder). ASD merupakan istilah yang dapat merangkum diagnostik gangguan pervasif seperti gejala autistik masa kanak-kanak, gangguan autistik, autism tipikal, Syndrome Asperger dan Pervasive Developmental NotOtherwise Specified (PDD-NOS). ASD merupakan 
kondisi yang berlanjut hingga remaja dan masa dewasa, meskipun anak mengalami perkembangan. Simptom atau gejala-gejalanya bervariasi. Anak-anak ASD mempunyai kisaran luas temperamen dan $I Q$.

Gangguan Spectrum Autisme atau biasanya disebut dengan Autistic Spectrum Disorder (ASD) adalah gangguan perkembangan yang secara umum tampak ditiga tahun pertama kehidupan anak (Chris W dan Barry W, 2007: 3). Sedangkan Autistic Spectrum Disorder (ASD) menurut Puspita, D. (2002 : 12) merupakan: Suatu gangguan perkembangan yang didalamnya terdapat sekumpulan gejala yang dialami oleh anak pada usia 3 tahun, gangguan perkembangan tersebut meliputi beberapa aspek yaitu: kualitas kemampuan interaksi sosial dan emosional, kualitas yang kurang dalam kemampuan komunikasi timbal balik dan minat yang terbatas disertai gerakan-gerakan berulang tanpa tujuan.

Angka autisme saat ini sudah mulai meningkat pesat hal ini dikarenakan berubahnya sistem diagnosa dan kriteria yang digunakan untuk menegakkan diagnosa. Salah satunya diagnosa yang digunakan secara global di seluruh penjuru dunia untuk mendeteksi autisme adalah Diagnostic and Statistical of Mental Disorder ke IV (DSM-IV) yang dibuat oleh American Psychiatric Association (APA) atau International Classification of Diseases10 (ICD-10) tahun 1994, yang merupakan suatu sistem diagnosis yang dibuat oleh WHO. Kedua sistem ini menyebutkan tentang Pervasive Developmental Disorders sebagai berikut:

Isi dari DSM IV tersebut terdapat beberapa kriteria yang menyangkut pada anak dengan
Autistic Spectrum Disorder (ASD), diantaranya sebagai berikut: Terdapat paling sedikit enam pokok dari kelompok 1, 2 dan 3 yang meliputi paling sedikit dua pokok dari kelompok 1, paling sedikit satu pokok dari kelompok 2 dan paling sedikit satu pokok dari kelompok 3.

Gangguan kualitatif dalam interaksi sosial yang ditunjukkan dengan: a) Ciri gangguan yang jelas dalam penggunaan berbagai perilaku non verbal (bukan lisan) seperti kontak mata, ekspresi wajah, gesture, dan gerak isyarat untuk melakukan interaksi sosial; b) Ketidakmampuan mengembangkan hubungan pertemanan sebaya yang sesuai dengan tingkat perkembangannya; c) Ketidakmampuan turut merasakan kegembiraan orang lain; d) Ketidakmampuan dalam berhubungan emosional secara timbal balik dengan orang lain; Gangguan kualitatif dalam berkomunikasi yang ditunjukkan oleh paling sedikit salah satu dari berikut ini: (a) Keterlambatan atau kekurangan secara menyeluruh dalam berbahasa lisan (tidak disertai usaha untuk mengimbanginya dengan penggunaan gestur atau mimik muka sebagai cara alternatif dalam berkomunikasi); (b) Ciri gangguan yang jelas pada kemampuan untuk memulai atau melanjutkan pembicaraan dengan orang lain meskipun dalam percakapan sederhana; (c) Penggunaan bahasa yang repetitive (diulang-ulang) atau stereotype (meniru-niru) atau bersifat idiosinkratik (aneh); (d) Kurang beragamnya spontanitas dalam permainan purapura atau meniru orang lain yang sesuai dengan tingkat perkembangannya; (e) Pola minat perilaku yang terbatas, repetitive, dan stereotype seperti yang ditunjukkan oleh paling tidak satu dari yang

Tabel 1. Berbagai gangguan yang termasuk dalam Pervasive Developmental Disorders

\begin{tabular}{|l|l|l|}
\hline No & DSM - IV & ICD - 10 \\
\hline 1. & Autistic Disorder & Childhood Autism \\
\hline 2. & $\begin{array}{l}\text { Pervasive Developmental Disorder } \\
\text { Not Otherwise Specified (PDD-NOS) }\end{array}$ & Atypical Autism \\
\hline 3. & Rett's Disorder & Rett's Syndrom \\
\hline 4. & Childhood Disintegrative Disorder & Other Chidhood Disintegrative Disorder \\
\hline 5. & Tidak ada & $\begin{array}{l}\text { Overactive Disorder with Mental } \\
\text { Retardation with Stereotype Movement }\end{array}$ \\
\hline 6. & Asperger's Disorder & Asperger' Syndrom \\
\hline 7. & DD-NOS & $\begin{array}{l}\text { Other Pervasive Developmental } \\
\text { Disorder }\end{array}$ \\
\hline 8. & PDD-NOS & $\begin{array}{l}\text { Pervasive Developmental Disorder, } \\
\text { Unspecified }\end{array}$ \\
\hline
\end{tabular}

Sumber: Ikatan Dokter Indonesia www.idai.com 
berikut ini: a) Meliputi keasyikan dengan satu atau lebih pola minat yang terbatas atau stereotype yang bersifat abnormal baik dalam intensitas maupun fokus; b) Kepatuhan yang tampaknya didorong oleh rutinitas atau ritual spesifik (kebiasaan tertentu) yang nonfungsional (tidak berhubungan dengan fungsi); c) Perilaku gerakan stereotype dan repetitive (seperti terus menerus membuka - tutup genggaman, memuntir jari atau tangan atau menggerakkan tubuh dengan cara yang kompleks; dan d) Keasyikan yang terus menerus terhadap bagian-bagian dari sebuah benda.

Seorang anak didiagnosis harus memenuhi kriteria untuk dapat disebut gangguan autistik. Namun harus diperhatikan bahwa gejala pada gangguan autistik sangat bervariasi dari anak ke anak. Tidak semua anak menunjukkan gejala yang sama jenisnya, dan tidak semua anak menunjukkan gejala sama berat. Perbedaan gejala tersebut bukan hanya dalam dua dimensi (lebih ringan atau lebih berat) tetapi bersifat multidimensi, sebagian gejala dapat lebih ringan ataupun sebaliknya.

Memperhatikan pengertian diatas maka dapat disimpulkan bahwa anak autisme sesungguhnya merupakan sekumpulan gejala klinis yang dilatar belakangi berbagai faktor yang sangat bervariasi, berkaitan satu sama lain dan unik, karena tidak sama untuk masing-masing kasus. Oleh karena itu, pula secara klinis, ditemukan beberapa gejala yang tumpang tindih dengan gejala-gejala dari beberapa gangguan perkembangan yang lain, dimana gradasi manifestasi gangguannya pun sangat lebar antara yang berat dan yang ringan dari setiap kasusnya. Disatu sisi terdapat anak yang memiliki sedikit gejala dari diagnosa DSM IV tersebut. Maka dari kasus seperti inilah muncul istilah gangguan spektrum autisme atau Autistic Spectrum Disorders (ASD). Di mana pengertian dari $A S D$ itu sendiri merupakan suatu gangguan perkembangan kualitatif yang terjadi pada anak diusia 3 tahun yang meliputi aspek interaksi sosial, komunikasi dan perilaku.

\section{Karakteristik Anak Autistic Spectrum Disorder (ASD)}

Karakteristik dari anak dengan Autistic Spectrum Disorder (ASD) menurut Chris W dan Barry W (2007
: 60) adalah sebagai berikut : 1) Anak dengan Autistic Spectrum Disorder cenderung focus pada detail gambar; 2) Berkonsentrasi pada suatu bagian kecil dari lukisan dan situasi; 3) Konsentrasi pada pengalaman sensoris tertentu seperti: bau, rasa, penglihatan, suara dan rabaan; 4) Sulit melihat keseluruhan lukisan dan memahaminya; 5) Sulit memahami pikiran atau perasaan orang lain; 6) Sulit memahami bahwa mereka diharapkan mengubah cara mereka bersikap bergantung dimana dan pada siapa mereka berhadapan; 7) Sulit memprediksi apa yang akan dilakukan orang kemudian; 8) Sulit menginterpretasikan ekspresi wajah yang berbeda; 9) Sulit paham mengapa tingkah laku mereka dapat membuat kesal orang lain; dan 10) Sulit memahami sikap tubuh dan tanda non verbal.

Hal senada dikemukakan menurut Siegel, 1996 dalam Sufia, K. (2009 : 15 -17) yang mengatakan bahwa beberapa individu $A S D$ memiliki ciri khas atau karakteristik tertentu seperti: 1) Visual Thinking, kebanyakan dari anak $A S D$ berpikir secara visual, mereka lebih mudah memahami hal-hal yang konkrit dibandingkan dengan yang abstrak; 2) Processing problems, gangguan perkembangan pada daerah tertentu di otak, mengakibatkan anak $A S D$ mengalami kesulitan dalam memproses data. Mereka cenderung terbatas dalam memahami "common sense" atau menggunakan akal sehat/daya nalar. Selain itu, mereka juga sulit mengingat sesuatu sambil mengerjakan hal lain dan sulit memahami bahasa verbal; 3) Sensory sensitivities, perkembangan yang kurang optimal pada sistem neurobiologis individu $A S D$ juga sedikit banyak mempengaruhi perkembangan indera mereka. Beberapa hal yang sering dilaporkan terjadi adalah adanya : sound sensitivity, touch sensitivity, dan rhytm difficulties; 4) Communication frustrations, gangguan perkembangan bicara bahasa yang terjadi pada individu $A S D$ membuat mereka sering frustrasi karena masalah komunikasi. Selain itu, individu $A S D$ juga sulit mengungkapkan diri, sehingga mereka suka berteriak dan berperilaku 
negatif hanya sekedar mendapatkan apa yang diinginkannya; 5) Social and emotional issues, ciri lain yang sangat dominan adalah fiksasi atau keterpurukan akan sesuatu yang membuat individu $A S D$ cenderung berpikir secara kaku. Akibatnya individu $A S D$ sulit beradaptasi atau memahami perubahan yang terjadi sehari-hari; 6) Problems of control, berbagai gangguan perkembangan neurologi di otak menjadikan masalah individu $A S D$ menjadi semakin kompleks. Mereka mengalami kesulitan dalam mengontrol diri sendiri, yang terwujud dalam bentuk masalah perilaku. Cenderung berperilaku ritual dengan pola tertentu dan ada yang keterpakuan pada beberapa jenis objek dan sebagian dari mereka juga memiliki ketakutan yang luar biasa pada halhal yang tidak ia mengerti; 7) Problems of tolerance, kepekaan yang berlebihan akan rangsang stimulus tertentu, membuat individu $A S D$ menarik diri dari lingkungannya. Mereka kurang dapat mentolerir rangsangan-rangsangan tersebut dan ini merupakan masalah sensori di tubuhnya; 8) Problems of connection, berbagai masalah yang berkaitan dengan kemampuan individu menalar, yaitu: (a) Attention problems: masalah pemusatan perhatian, terus menerus terdistraksi; (b) Perceptual problems: masalah proses persepsi, bingung sehingga menghindar dari orang lain; (c) System integration problems: proses informasi di otak bekerja secara mono (tunggal), sehingga sulit memproses beberapa hal sekaligus; (d) Leftright hemisphere integration problems: otak kiri tidak secara konsisten mengetahui apa yang terjadi pada otak kanan (dan sebaliknya), sehingga sepenuhnya tidak sadar pada apa yang sedang terjadi.

\section{Kemampuan Motorik Anak Autistic Spectrum Disorder (ASD)}

Kondisi perkembangan mental yang tertinggal, berdampak pada kemampuan motorik anak $A S D$. Hal ini disebabkan adanya gangguan pada sistem syaraf pusat, Oleh karena itu, anak autisme pada umumnya memiliki kecakapan motorik yang lebih rendah dibandingkan dengan kelompok anak sebayanya, baik secara kualitatif maupun kuantitatif (Sherill, 1984; Astati, 2001). Hal ini ditunjukkan dengan kekurangmampuan dalam aktifitas motorik untuk tugas-tugas yang memerlu- kan kecepatan gerakan serta dalam melakukan reaksi gerak yang memerlukan koordinasi motorik dan keterampilan gerak yang lebih kompleks.

Sunardi dan Sunaryo (2006 : 118) menyatakan bahwa pada anak autis seringkali ditemukan mengalami permasalahan dalam motorik halus. Sedangkan menurut Ferizal Masra (dalam Tempo : 2008) selain karakteristik di atas, anak dengan Autistic Spectrum Disorder (ASD) menunjukkan gejala gangguan perilaku motorik. Kebanyakan anak autisme menunjukkan adanya stereotip, seperti bertepuk-tepuk tangan dan menggoyanggoyangkan tubuh. Hiperaktif biasa terjadi terutama pada anak prasekolah. Namun, sebaliknya, dapat terjadi hipoaktif. Beberapa anak juga menunjukkan gangguan pemusatan perhatian dan impulsivitas. Juga didapatkan adanya koordinasi motorik yang terganggu, tiptoe walking, clumsiness, kesulitan belajar mengikat tali sepatu, menyikat gigi, memotong makanan, dan mengancingkan baju.

Hal senada dikemukakan oleh Veskarisyanti, A. (2008:47) bahwa: "Beberapa anak penyandang autisme mengalami gangguan pada perkembangan motorik, otot kurang kuat untuk berjalan, serta keseimbangan tubuhnya kurang baik, selain itu mereka memiliki gangguan perkembangan dalam motorik kasarnya". Gerakan motorik anak $A S D$ terkadang mengalami gangguan karena sensitivitas indera yang juga terganggu. Salah satu indikator gangguan motorik atau kecanggungan motorik adalah bahwa sebagian anak $A S D$ belajar berjalan beberapa bulan lebih lambat dari anak kebanyakan seperti yang terjadi pada pengidap Syndrom Asperger (Manjiviona dan Prior 1995). Sekitar 40 persen anak ASD memiliki beberapa ketidak-normalan kepekaan inderawi (Rimland, 1990). Sebagai akibatnya menunjukkan hasil bahwa buruknya koordinasi motorik bisa mempengaruhi cukup banyak kemampuan, termasuk keterampilan motorik halus dan kasar seperti keterampilan lokomosi, keterampilan bola, keseimbangan, deksteritas manual, gerakan cepat dan menulis dengan tangan.

\section{Konsep Dasar Menulis}

Menulis adalah suatu kegiatan yang membutuhkan perseptual, motor, kognitif yang bernilai kompleks. Keterampilan menulis merupakan 
aktivitas fungsional anak yang dapat mempengaruhi kepuasan individu anak, kreativitas, produktivitas serta prestasi akademik di sekolah. Soemarmo Markam (1987: 7) menjelaskan menulis adalah mengungkapkan bahasa dalam bentuk simbol dan gambar dan merupakan aktivitas kompleks yang mencakup gerakan lengan, tangan, jari dan mata secara terintegrasi. Proses menulis pada hakikatnya merupakan suatu proses neurofisiologis. Russel dan Wanda (1986: 16).

Proses menulis digambarkan oleh Fairbank yang dikutip oleh Sanders (1982: 22) dalam Pendidikan Bagi Anak Berkesulitan Belajar (dalam Mulyono Abdurrahman). Rangsangan dari lingkungan yang masuk melalui indera pendengaran, penglihatan, dan taktil-kinestetis ( 1 1, S2, S3) masuk ke sensasi (A), kemudian ke persepsi (B), ke pengertian $(C)$; selanjutnya diasosiasikan pada korteks auditori, korteks visual, dan korteks kinestetis. Setelah terjadi asosiasi, selanjutnya masuk ke sumber atau korteks, yaitu daerah pikiran dan ide; dan melalui impul-impul saraf dilakukan respons melalui transmiten 2, yaitu lengan dan tanagn (T2) dalam wujud tulisan. Sesaat setelah selesai menulis, anak akan segera melihat kebenaran tulisan tersebut. Dengan demikian, dapat disimpulkan bahwa dalam menulis terjadi suatu aktivitas yang didukung oleh beberapa indera; dan anak harus mampu mentransfer dan mengintegrasikan antara kemampuan visual, auditori, kinestetis, maupun berpikir. Baik bicara yang keluar melalui T1 maupun menulis melalui T2 memiliki ciri yang sama, yaitu produktif dan ekspresif.

\section{Kemampuan Menulis}

Menurut Cornhill dan Case Smith yang dikutip dari Makalah Konferensi Nasional Autisme - I (Hiremawati, A : 2007), terdapat beberapa faktor kematangan fisik yang berpengaruh dengan kemampuan menulis pada anak yaitu kinestesia, motor planning, koordinasi mata-tangan, integrasi visual-motor, dan keterampilan manipulasi tangan. Penjelasannya adalah sebagai berikut: a) Kinestesia, adalah kesadaran akan persepsi berat obyek, arah persendian dan gerakan anggota badan. Akurasi persepsi kinestetik akan berpengaruh pada keterampilan menulis pada anak; b) Perencanaan motorik (motor planning). Dalam menulis, formasi huruf secara sekuensis memerlukan keterampilan perencanaan motorik secara terus menerus dan berpengaruh terhadap kemampuan anak pada waktu merencanakan, mengurutkan, serta membentuk huruf pada waktu menulis. Perencanaan motorik sangat berkaitan dengan kinestesia. Ketika anak memiliki limitasi

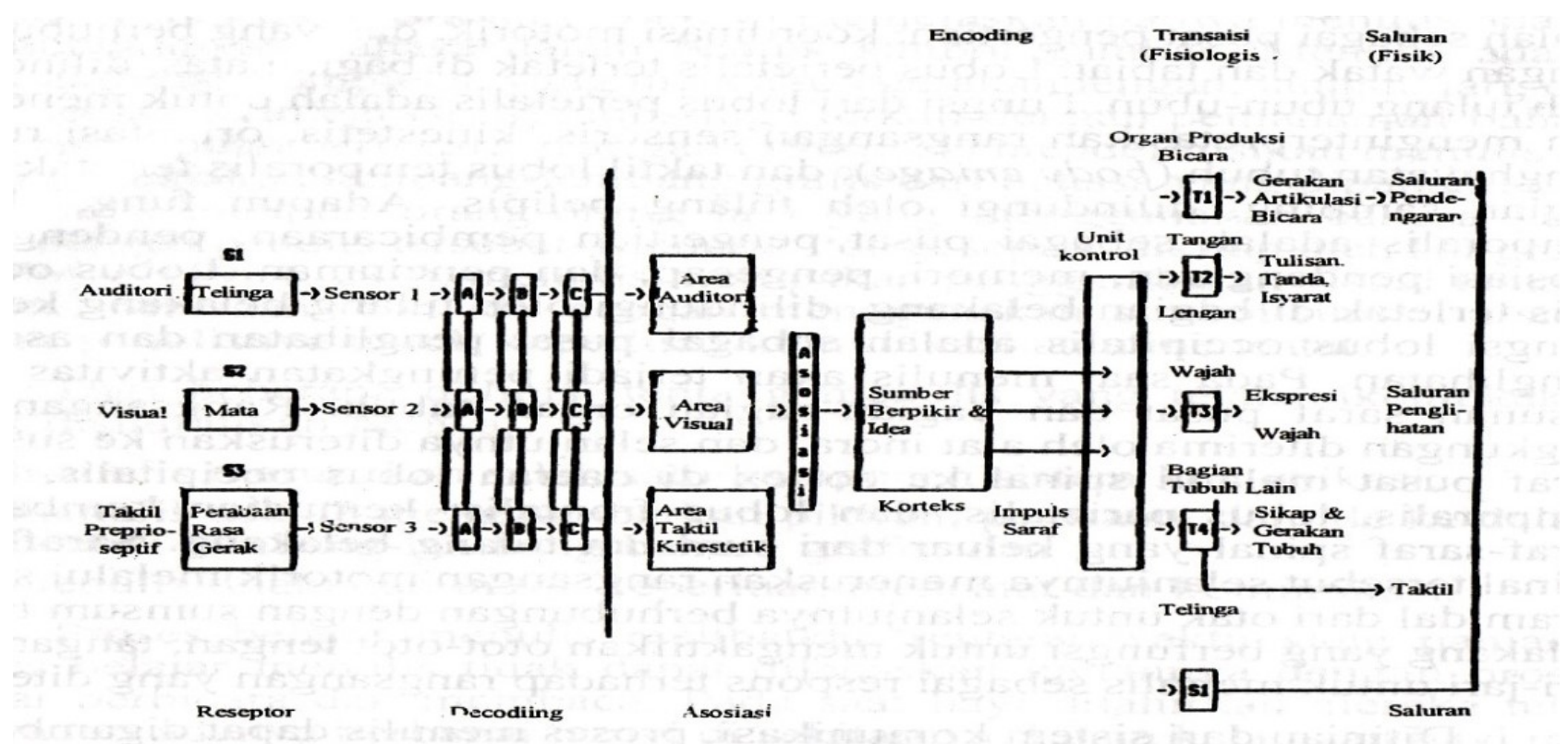

Gambar 1. Proses Menulis Ditinjau dari Sudut Komunikasi (Diadaptasi dari Fairbank Seperti Dikutip oleh Sanders, 1983: 20) 
akan kesadaran gerak dan mengarahkan sekuensis gerakan tangan. Terdapat dua macam jenis gangguan perencanaan motorik. Jenis yang pertama adalah anak mengalami kesulitan untuk merencanakan ide gerakan yang harus dilakukan dan jenis yang kedua adalah kesulitan untuk melakukan gerakan yang telah direncanakan terputus; c) Koordinasi mata-tangan (eye-hand coordination), sangat diperlukan untuk menulis terutama ketika anak menulis di atas kertas bergaris. Pada waktu menulis huruf kafital, hasil tulisan tangan sangat tergantung dari input dan kesinambungan petunjuk sistem visual. Sebagai contoh, untuk menulis bentuk huruf yang sangat spesifik anak memerlukan sistem visual yang terus menerus. Peran sistem visual pada waktu menulis akan bertambah dominan ketika fungsi kinestetik mengalami gangguan. Dengan kata lain, pada waktu menulis anak bergantung pada sistem visual (penglihatan) untuk mengkompensasi kelemahan feed back kinestetik; d) Intelegensi visual motorik, merupakan variabel yang penting pada aktivitas menulis, terutama ketika anak mengkopi huruf dari tulisan cetak ke huruf latin yang bergandengan satu dengan yang lainya. Pada waktu mengkopi anak harus memperhatikan dan melihat bentuk serta karakteristik huruf satu persatu. Pada waktu yang sama anak harus memanipulasi alat tulis yang dipakai pada waktu menulis. Dengan demikian ketika anak menggerakkan tangan saat menulis, sistem visual memberikan informasi tentang layout ruang yang tersedia untuk menulis. Disamping itu kesadaran akan lingkungan sekitar akan memberikan kesempatan pada individu untuk mengantisipasi kejadian yang akan terjadi serta merencanakan tindakan/gerak yang akan dilakukan.

Menulis merupakan aktivitas neurofisiologis yang kompleks dimana kemampuan motorik merupakan salah satu hal penting yang harus ada didalamnya. Menurut Lerner (1985: 402) ada beberapa faktor yang mempengaruhi kemampuan anak untuk menulis, 1) motorik, 2) perilaku, 3) persepsi, 4) memori, 5) kemampuan melaksanakan cross modal, 6) penggunaan tangan yang dominan, dan 7) kemampuan memahami instruksi. Anak yang perkembangan motoriknya belum matang atau mengalami gangguan, akan mengalami kesulitan dalam menulis; tulisannya tidak jelas, terputus-putus, tidak mengikuti garis atau bahkan memerlukan waktu yang lama untuk menuliskan sebuah kata atau kalimat.

\section{Latihan Sensorimotor}

Luh Karunia Wahyuni menyatakan mengenai pendekatan terapi sensorimotor dalam Konferensi Nasional Neurodevelopmental II (2006) dalam Dwi, H, A. (2007:9) sebagai berikut: "Suatu pendekatan yang mempergunakan organ sensoris dan motoris yang dimanipulasi sedemikian rupa sehingga terjadi perbaikan sensori, motorik, dan persepsi yang pada gilirannya akan meningkatkan kapasitas belajar untuk keterampilan yang lebih kompleks".

Latihan sensorimotor adalah latihan yang bertujuan untuk meningkatkan kemampuan sensorimotor yang terdiri dari kemampuan visual, taktil, proprioseptif, vestibuler, auditoris dan kinestetik/gerakan motorik dengan menggunakan alat.

Menurut piaget yang dikutip dari buku Berkesulitan Belajar, belajar sensorimotor pada masa ini merupakan bangunan dasar bagi perkembangan perseptual dan kognitif yang lebih kompleks. Sensorimotor adalah gabungan antara masukan sensasi (input of sensation) dengan keluaran aktivitas motorik (output of motor activity). Sensasi (sensation) adalah proses yang dirasakan dan dialaminya energi rangsangan tertentu oleh indera kita. Sensasi tersebut menunjukkan adanya suatu proses yang terjadi di dalam sistem saraf pusat. Manusia memiliki indera-indera yang berfungsi sebagai saluran penerima data kasar dari lingkungannya yaitu penglihatan (visual), pendengaran (auditoris), perabaan (taktil), kinestetik, penciuman (olfaktory), dan pengecapan.

Sehingga latihan sensorimotor adalah suatu kegiatan yang bertujuan untuk mengoptimalkan proses biologis pada otak dalam mengolah berbagai informasi sensorik dan motorik, yang kemudian dipergunakan dengan sebaik-baiknya terutama dalam meningkatkan kemampuan menulis. Karena kemampuan sensorimotor (VITAPROVAK) adalah salah satu kemampuan prasarat yang harus dikuasai siswa saat melakukan aktivitas menulis. 


\section{Metode Penelitian}

\section{Lokasi dan Subyek Penelitian}

Lokasi dilaksanakannya penelitian ini adalah di SD Sembilan Mutiara, yang beralamat di Perumahan Taman Hijau, Jalan Situ Aksan Permai no. 43 Bandung. Sedangkan subyek dalam penelitian ini adalah seorang anak dengan Autistic Spectrum Disorder (ASD) kelas 6 SD.

Rancangan yang digunakan adalah subjek tunggal atau Single Subject Research (SSR) yaitu suatu metode yang bertujuan untuk memperoleh data yang diperlukan dengan melihat hasil ada tidaknya pengaruh yang terjadi dari suatu perlakuan (intervensi) yang diberikan. Target behavior dalam penelitian ini lebih dari satu dan terdapat dua satuan ukur yang berbeda, maka pada penelitian ini menggunakan dua pola desain yaitu pola desain baseline jamak (multiple baseline cross variable) dan pola disain A - B - A. Desain pertama yaitu desain baseline jamak untuk tiga target behavior (mempertahankan posisi kepala dan tubuh/vestibular, stabilitas tangan kiri/taktil, serta keluwesan jari-jari dan tangan/ kinestetik). Menurut Sunanto (2006:51) menyatakan bahwa "Desain baseline jamak merupakan desain yang memiliki validitas internal yang lebih baik dibandingkan dengan desain yang lain". Ada tiga variasi atau tipe dalam desain baseline jamak ini diantaranya yaitu 1) multiple baseline cross variables (disain baseline jamak antarvariabel), 2) multiple baseline cross conditions (disain baseline jamak antarkondisi, 3) multiple baseline cross subjects (disain baseline jamak antarsubyek).

Sementara itu tipe desain yang akan digunakan pada penelitian ini adalah tipe multiple baseline cross variables atau disebut juga dengan desain baseline jamak antarvariabel menurut Juang Sunanto, Takeuchi, Koji, dan Nakata, Hideo, (2006:53) "Merupakan suatu intervensi yang diperkirakan dapat memberikan efek terhadap dua atau lebih perilaku sasaran (target behavior)". Meskipun demikian masingmasing perilaku yang ingin diubah (target behavior) harus independen sehingga pengaruh atau efek dari intervensi masing-masing target behavior dapat diketahui.

\section{Teknik Pengumpulan Data}

Pada penelitian ini, teknik pengumpulan data yang digunakan yaitu dengan melakukan tes menulis dan tes performance atau tes perbuatan. Selain itu, pengumpulan data yang mendukung dalam penelitian ini yaitu melalui beberapa kegiatan seperti observasi dan dokumentasi.

\section{Instrumen Penelitian}

Instrumen yang digunakan untuk mengumpulkan data dalam penelitian ini ada tiga jenis yaitu pertama, pemberian intervensi latihan sensorimotor berupa empat jenis latihan yang disusun dalam bentuk Rencana Pelaksanaan Pembelajaran (RPP) untuk melatih kemampuan TAPROVAK (Taktil, Propioseptif, Vestibular dan Kinestetik), yang kedua yaitu observasi/pengamatan serta yang ketiga adalah tes kemampuan menulis untuk mengetahui kemampuan menulis dan hasil menulis anak sebelum, selama dan setelah diberikan intervensi latihan sensorimotor. Selain itu juga digunakan lembar pencatatan (Recording Sheet) sebagaimana yang telah digambarkan pada prosedur penelitian.

\section{Hasil Penelitian dan Pembahasan Kemampuan Vestibular}

Tabel 2. Skor Hasil Penelitian Baseline (A) Kemampuan Vestibular (kemampuan mempertahankan posisi kepala dan tubuh) anak ASD

\begin{tabular}{|c|c|c|c|c|}
\hline \multicolumn{5}{|c|}{ Kemampuan Vestibular Anak Autistic } \\
Spectrum Disorder (ASD)
\end{tabular}

Berdasarkan tabel 2 skor yang diperoleh subyek pada sesi pertama sebesar 55 detik, sesi kedua naik menjadi 67 detik, sementara itu pada sesi ketiga dan keempat subyek mengalami kenaikan perolehan skor menjadi 60 detik. Sehingga kecenderungan arah grafik pada fase baseline ini adalah mendatar. Hal tersebut dapat dilihat pada Grafik 1. 


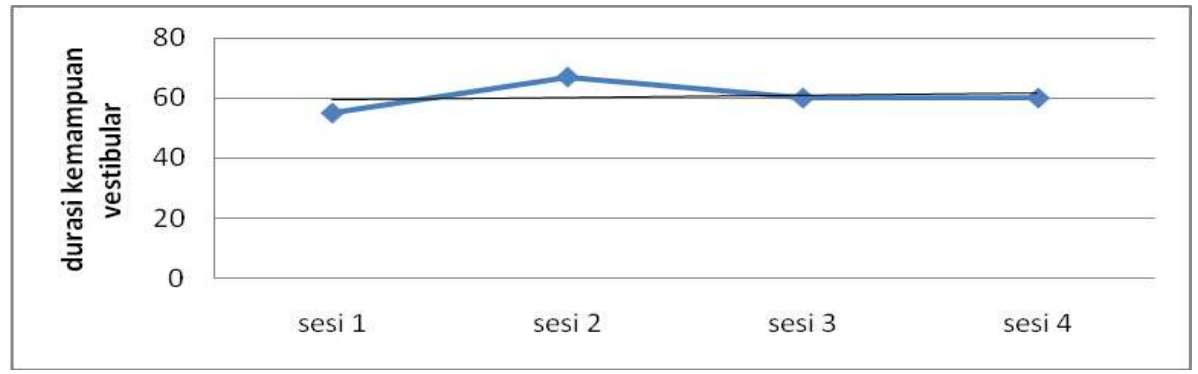

Grafik 1. Kecenderungan arah kemampuan vestibular pada fase baseline (A)

Sedangkan pada tingkat kestabilan perubahan data diperoleh hasil sebesar $75 \%$ hal tersebut menunjukkan bahwa subyek sudah berada pada kondisi variabel menuju stabil maka fase intervensi sudah bisa dilakukan.

Dengan melihat hasil skor yang diperoleh subyek dari sesi kelima sampai sesi ke-16 memiliki kecenderungan arah menaik, untuk lebih jelasnya lagi kecenderungan arah tersebut dapat dilihat pada grafik 2 .
Menurut perhitungan trend stability pada empat sesi awal diperoleh hasil $67 \%$ hal tersebut dapat dikatakan bahwa subyek sudah berada pada kondisi variabel menuju stabil sehingga intervensi untuk variabel terikat atau target behavior selanjutnya dapat dilakukan, sementara itu trend stability secara keseluruhan diperoleh hasil $75 \%$. Analisis kemampuan vestibular pada fase baseline (A) dan intervensi (B) dalam analisis ini akan terlihat perubahan kondisi pada variabel

Tabel 3. Skor hasil Penelitian Intervensi (B) Kemampuan Vestibular (kemampuan mempertahankan posisi kepala dan tubuh)

\begin{tabular}{|c|c|c|c|c|c|c|c|c|c|c|c|c|}
\hline \multicolumn{10}{|c|}{ Kemampuan Vestibular Anak Autistic Spectrum Disorder (ASD) } \\
\hline Sesi & Sesi & Sesi & Sesi & Sesi & Sesi & Sesi & Sesi & Sesi & Sesi & Sesi & Sesi & Jum- \\
5 & 6 & 7 & 8 & 9 & 10 & 11 & 12 & 13 & 14 & 15 & 16 & lah \\
\hline 80 & 84 & 96 & 100 & 110 & 116 & 120 & 128 & 133 & 142 & 142 & 142 & 1.393 \\
\hline
\end{tabular}

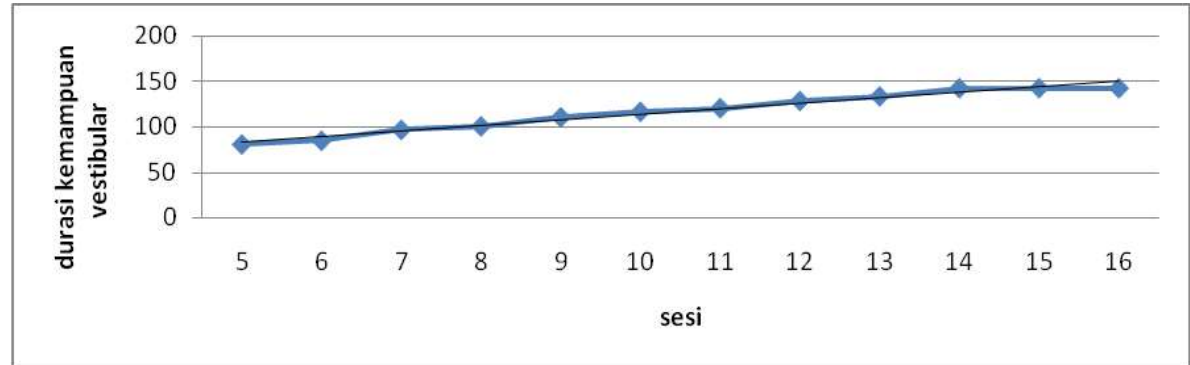

Grafik 2. Kecenderungan arah fase intervensi (B) kemampuan vestibular (kemampuan mempertahankan posisi kepala dan tubuh) anak ASD

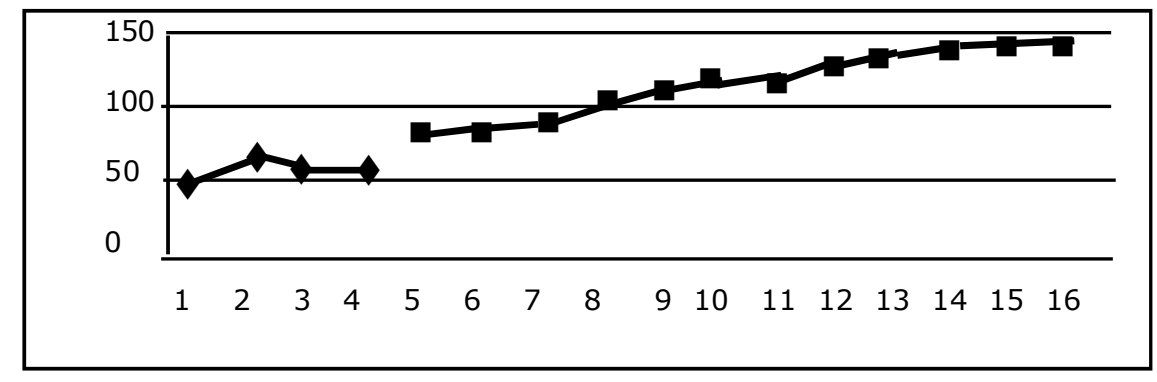

Grafik 3. Kemampuan vestibular pada fase baseline (A) dan intervensi (B) 
terikat atau target behavior yang disebabkan oleh latihan sensorimotor, untuk lebih jelasnya lagi dapat dilihat pada grafik 3 .

Pada grafik 3 menunjukkan bahwa pada fase baseline (A) subyek mengalami satu kali kenaikan yaitu pada sesi kedua selebihnya stabil pada skor 60 detik. Meskipun pada fase baseline (A) hanya empat sesi tetapi sudah berada pada kondisi stabil maka intervensi pun dapat dilakukan. Pada fase intervensi (B) yang dilakukan sebanyak 12 sesi terlihat peningkatan yang cukup baik. Hal ini dapat dilihat dari perubahan level dimana perubahan level tersebut dapat menunjukkan seberapa besar data berubah. Tingkat perubahan data dalam kondisi fase baseline $(A)$ adalah +5 dan pada fase intervensi tingkat perubahan datanya +62 , sementara itu tingkat perubahan data antar kondisi yang diperoleh subyek adalah +20 atau dapat dikatakan bahwa perubahan level tersebut membaik.

\section{Kemampuan Taktil}

Berdasarkan kecenderungan arah grafik kedelapan sesi tersebut secara umum menaik, hal tersebut dapat dilihat pada grafik 4 .
Sementara itu perhitungan trend stability yang diperoleh subyek adalah $75 \%$ hal ini menunjukkan bahwa semua skor yang diperoleh subyek berada pada rentang stabil, oleh karena itu pada fase baseline $(A)$ ini subyek sudah berada pada kondisi stabil.

Berdasarkan kecenderungan arah grafik kedelapan sesi tersebut secara umum menaik hal tersebut menunjukkan bahwa subyek setelah diberi perlakuan atau intervensi mengalami perubahan kearah yang positif. Untuk melihat kecenderungan arah secara detail dapat dilihat pada grafik 5 .

Pada perhitungan trend stability pada keempat sesi awal didapatkan hasil $50 \%$ dan hal itu sudah memenuhi kriteria stabil sehingga intervensi untuk variabel terikat atau target behavior yang selanjutnya bisa dilakukan, sementara itu trend stability secara keseluruhan diperoleh hasil $75 \%$.

Analisis kemampuan taktil pada fase baseline (A) dan intervensi (B). Dalam analisis ini akan terlihat pengaruh latihan sensorimotor terhadap peningkatan kemampuan taktil (kemampuan

Tabel 4. Skor Hasil Penelitian Pada Fase baseline (A) Kemampuan Taktil (kemampuan mempertahankan stabilitas tangan kiri)

\begin{tabular}{|c|c|c|c|c|c|c|c|c|}
\hline \multicolumn{7}{|c|}{ Kemampuan Taktil Anak Autistic Spectrum Disorder (ASD) } \\
\hline Sesi 1 & Sesi 2 & Sesi 3 & Sesi 4 & Sesi 5 & Sesi 6 & Sesi 7 & Sesi 8 & Jumlah \\
\hline 13 & 21 & 16 & 21 & 25 & 30 & 20 & 20 & 166 \\
\hline
\end{tabular}

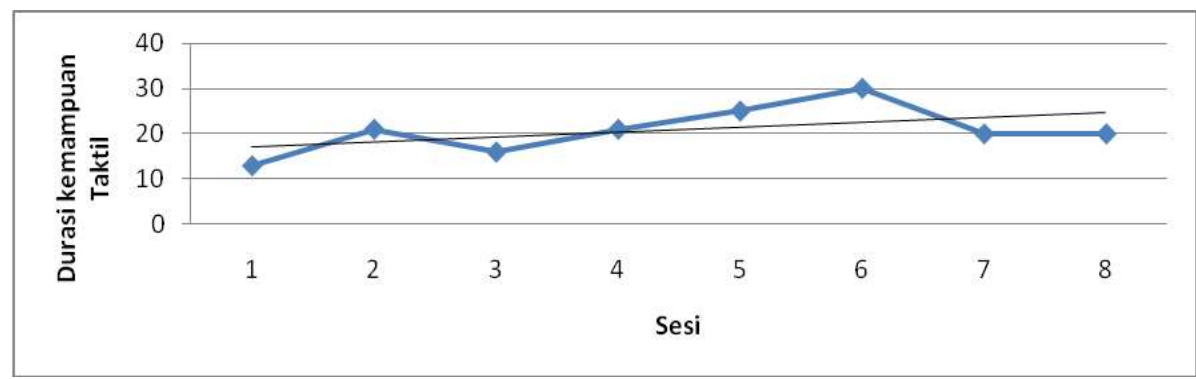

Grafik 4. Kecenderungan arah pada fase baseline (A) kemampuan taktil (kemampuan mempertahankan stabilitas tangan kiri)

Tabel 5. Skor Hasil Penelitian Pada fase Intervensi (B) Kemampuan Taktil (kemampuan mempertahankan stabilitas tangan kiri)

\begin{tabular}{|c|c|c|c|c|c|c|c|c|}
\hline \multicolumn{8}{|c|}{ Kemampuan Taktil Anak Autistic Spectrum Disorder (ASD) } \\
\hline Sesi 9 & Sesi10 & Sesi11 & Sesi12 & Sesi13 & Sesi14 & Sesi15 & Sesi16 & Jumlah \\
\hline 55 & 62 & 68 & 92 & 78 & 73 & 120 & 120 & 668 \\
\hline
\end{tabular}




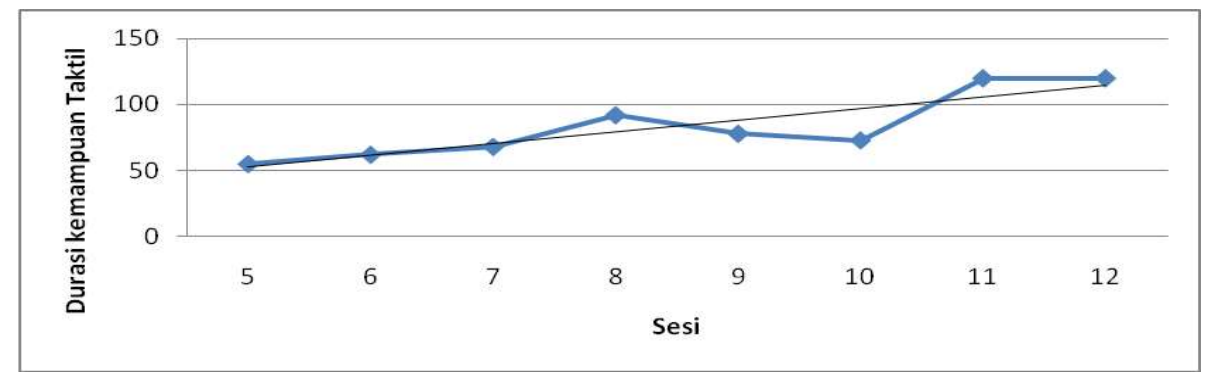

Grafik 5. Kecenderungan Arah Pada Fase Intervensi (B) Kemampuan Taktil (kemampuan mempertahankan stabilitas tangan kiri)

mempertahankan stabilitas tangan kiri), untuk lebih jelasnya lagi dapat dilihat pada grafik 6.

Grafik 6 menunjukkan bahwa pada fase baseline (A) skor yang diperoleh subyek mengalami sedikit kenaikan sehingga kecenderungan arah pada fase baseline (A) sedikit naik. Pada fase intervensi (B) skor yang diperoleh subyek cukup baik sehingga kecenderungan arah pada fase ini menaik. Peningkatan kemampuan taktil subyek
12 sesi tersebut secara umum mendatar, hal tersebut dapat terlihat pada grafik 7

Sementara itu perhitungan trend stability yang diperoleh subyek adalah $91,7 \%$. Hal ini menunjukkan bahwa waktu atau durasi dalam menuliskan sebuah paragraf yang diperoleh subyek pada fase baseline $(A)$ ini sudah berada pada kondisi stabil sehingga intervensi bisa dilakukan.

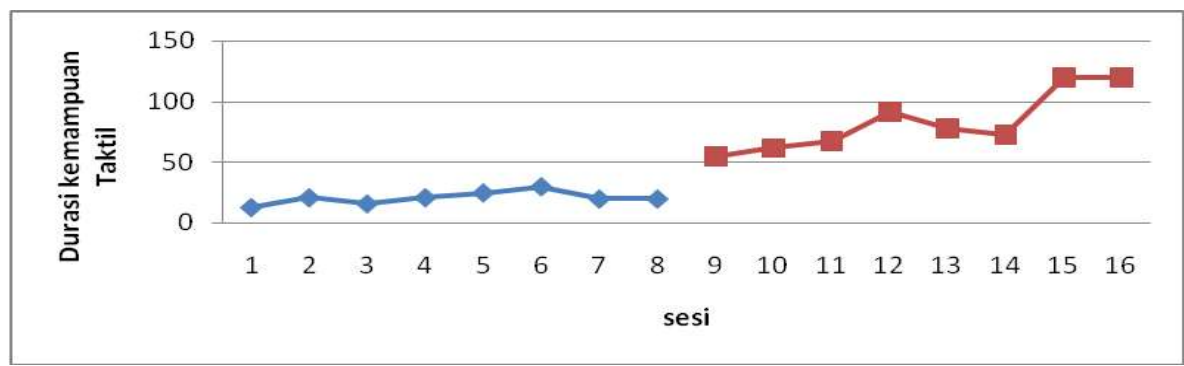

Grafik 6. Kemampuan Taktil (kemampuan mempertahankan stabilitas tangan kiri) pada Fase Baseline (A) dan Intervensi (B)

juga dapat dilihat dari perubahan level dalam kondisi pada fase baseline diperoleh +7 dan pada fase intervensi diperoleh +65 sedangkan perubahn level antar kondisi yang diperoleh subyek adalah +35 atau dapat dikatakan bahwa perubahan level tersebut membaik karena mengarah kearah yang lebih positif.
Hal ini menunjukkan bahwa subyek setelah diintervensi mengalami peningkatan kemampuan kinestetik kearah yang lebih baik. hal tersebut dapat dilihat pada grafik 10 .

\section{Kemampuan Kinestetik}

Tabel 6. Skor Hasil Penelitian pada Fase Baseline (A) Kemampuan Kinestetik (keluwesan gerakan jari dan tangan)

Berdasarkan kecenderungan arah grafik ke-

\begin{tabular}{|c|c|c|c|c|c|c|c|c|c|c|c|c|}
\hline \multicolumn{10}{c|}{ Kemampuan Kinestetik Anak Autistic Spectrum Disorder (ASD) } \\
\hline $\begin{array}{c}\text { Sesi } \\
1\end{array}$ & $\begin{array}{c}\text { Sesi } \\
2\end{array}$ & $\begin{array}{c}\text { Sesi } \\
3\end{array}$ & $\begin{array}{c}\text { Sesi } \\
4\end{array}$ & $\begin{array}{c}\text { Sesi } \\
5\end{array}$ & $\begin{array}{c}\text { Sesi } \\
6\end{array}$ & $\begin{array}{c}\text { Sesi } \\
7\end{array}$ & $\begin{array}{c}\text { Sesi } \\
8\end{array}$ & $\begin{array}{c}\text { Sesi } \\
9\end{array}$ & $\begin{array}{c}\text { Sesi } \\
10\end{array}$ & $\begin{array}{c}\text { Sesi } \\
11\end{array}$ & $\begin{array}{c}\text { Sesi } \\
12\end{array}$ & Jumlah \\
\hline 1100 & 1142 & 1138 & 900 & 1142 & 1142 & 1142 & 1142 & 1142 & 1142 & 1142 & 1142 & 13.411 \\
\hline
\end{tabular}




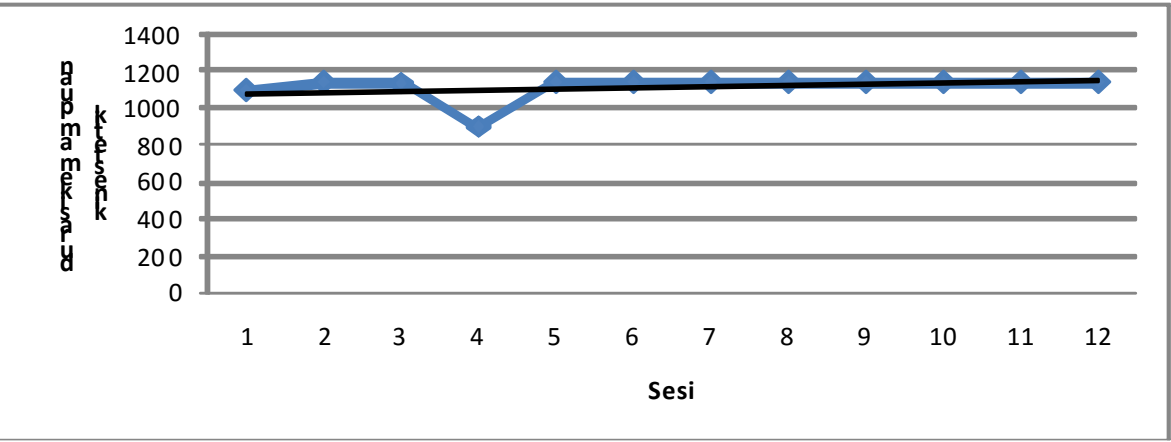

Grafik 7. Kecenderungan Arah pada Fase Baseline (A) Kemampuan Kinestetik (keluwesan gerakan jari dan tangan)

Tabel 7. Skor Hasil Penelitian pada Fase Intervensi (B) Kemampuan Kinestetik (keluwesan jari dan tangan)

\begin{tabular}{|c|c|c|c|c|}
\hline \multicolumn{5}{|c|}{ Kemampuan Kinestetik Anak Autistic Spectrum Disorder (ASD) } \\
\hline Sesi 13 & Sesi 14 & Sesi 15 & Sesi 16 & Jumlah \\
\hline 721 & 578 & 435 & 436 & 2.170 \\
\hline
\end{tabular}

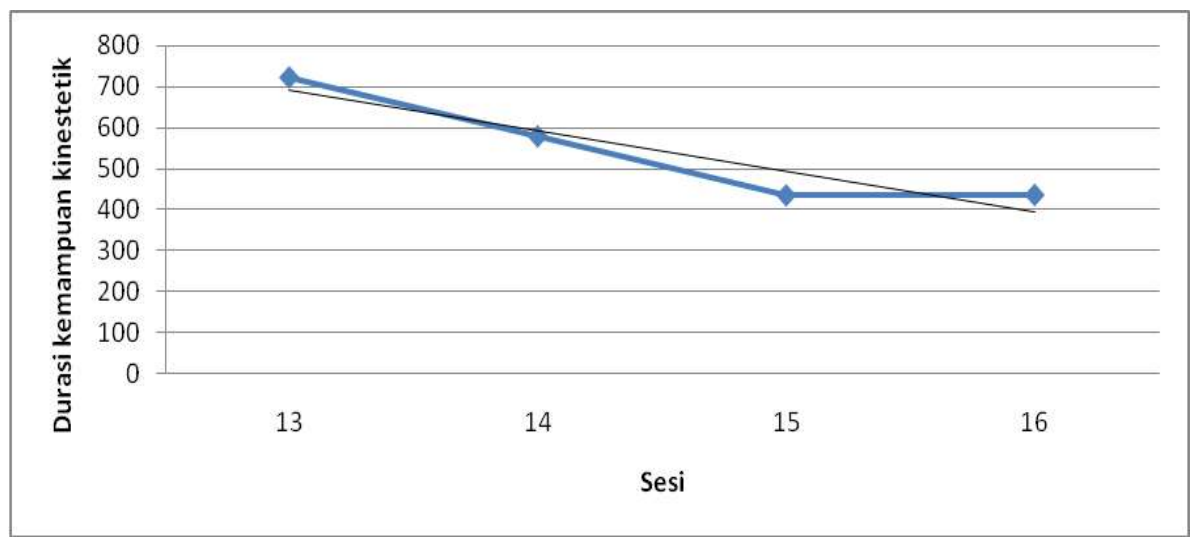

Grafik 8. Kecenderungan Arah pada Fase Intervensi (B) Kemampuan Kinestetik (keluwesan jari dan tangan)

Analisis kemampuan kinestetik pada fase baseline (A) dan intervensi (B) dalam analisis ini terlihat adanya pengaruh pada variabel terikat atau target behavior yang disebabkan oleh latihan sensorimotor, untuk lebih jelasnya lagi dapat dilihat pada grafik 9

Grafik 9 menunjukkan bahwa pada fase baseline (A) waktu atau durasi yang diperoleh

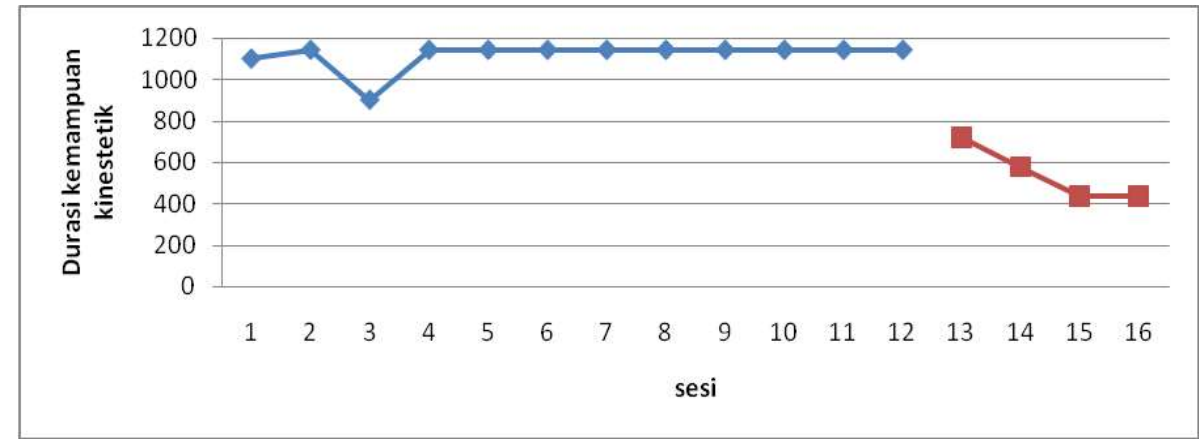

Grafik 9. Kemampuan Kinestetik pada Fase Baseline (A) dan Intervensi (B) 
subyek cukup signifikan, tidak ada nilai yang turun dan naik secara ekstrim, sehingga kecenderungan arah pada fase baseline $(A)$ ini mendatar. Pada fase intervensi (B) waktu atau durasi yang diperoleh subyek cukup baik yaitu waktu yang diperoleh subyek untuk menuliskan sebuah paragraf adalah menurun. Sehingga kecenderungan arah pada fase ini menurun. Peningkatan kemampuan kinestetik subyek juga dapat dilihat dari perubahan level, dimana perubahan level dalam kondisi yang diperoleh subyek pada fase baseline $(A)$ adalah +42 dan pada fase intervensi perubahan level dalam kondisi yang diperoleh subyek adalah -288 (negatif pada target behavior kinestetik berarti perubahan positif). Sedangkan perubahan level antar kondisi yang diperoleh subyek adalah -421 atau dapat dikatakan bahwa perubahan level tersebut membaik karena mengarah kearah yang lebih positif.
Berdasarkan grafik 10 tampak bahwa terjadi perubahan kemampuan dalam kemampuan kinestetik (keluwesan jari dan tangan yang dilihat dari waktu yang diperlukan untuk menuliskan sebuah paragraf) setelah diberikan intervensi. Pada fase baseline (A) kemampuan rata-rata kinestetik subyek adalah 1.118. Sementara pada saat diberikan intervensi rata-rata kemampuannya meningkat menjadi 543. Hal ini menunjukkan bahwa latihan sensorimotor memiliki pengaruh terhadap peningkatan kemampuan kinestetik subyek.

Pada grafik 11. terlihat bahwa disain multiple baseline cross variabel ini memiliki kontrol yang ketat terhadap eksperimen atau intervensi, hal ini dikarenakan pada kemampuan vestibular intervensi dilakukan setelah fase baseline $(A)$ yang dilakukan sebanyak empat sesi sudah berada pada kondisi stabil, sementara itu untuk fase

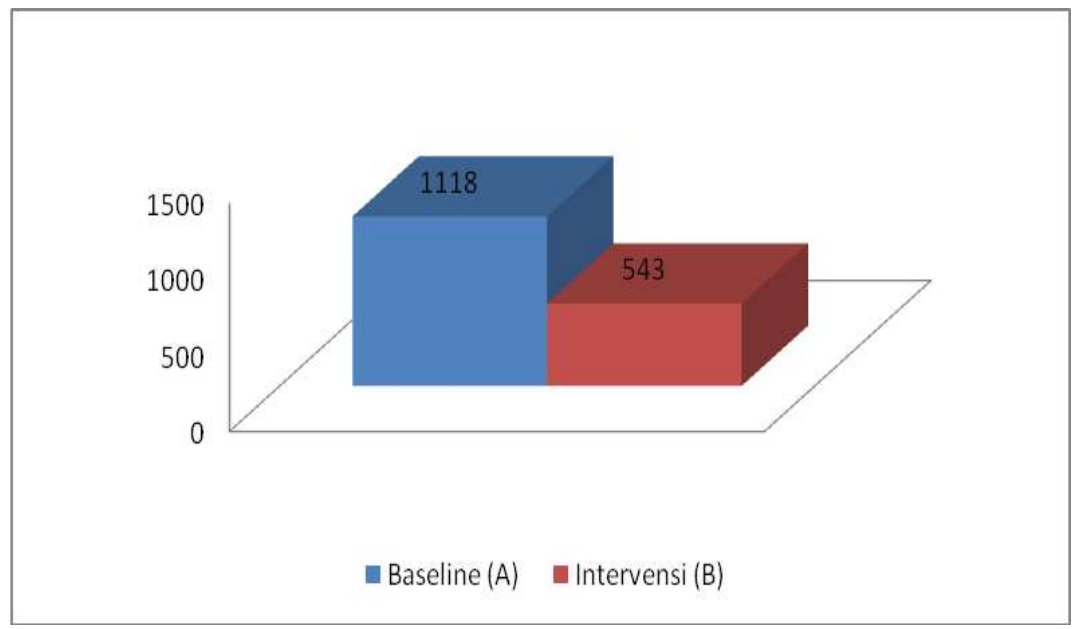

Grafik 10. Perbandingan Rata-rata Fase Baseline (A) dan Fase Intervensi (B) Kemampuan Kinestetik (keluwesan jari dan tangan)

Grafik 11. Hasil penelitian dengan disain multiple baseline cross variable (kemampuan vestibular, taktil dan kinestetik)

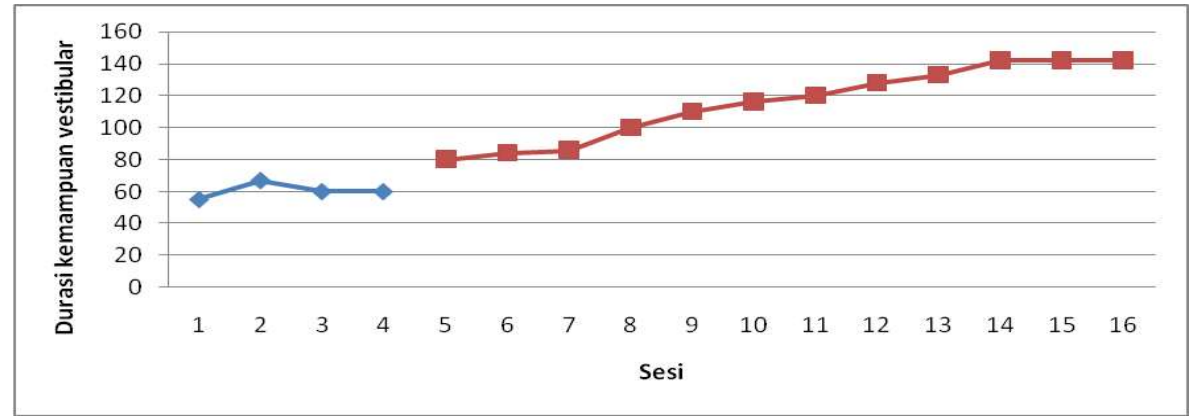



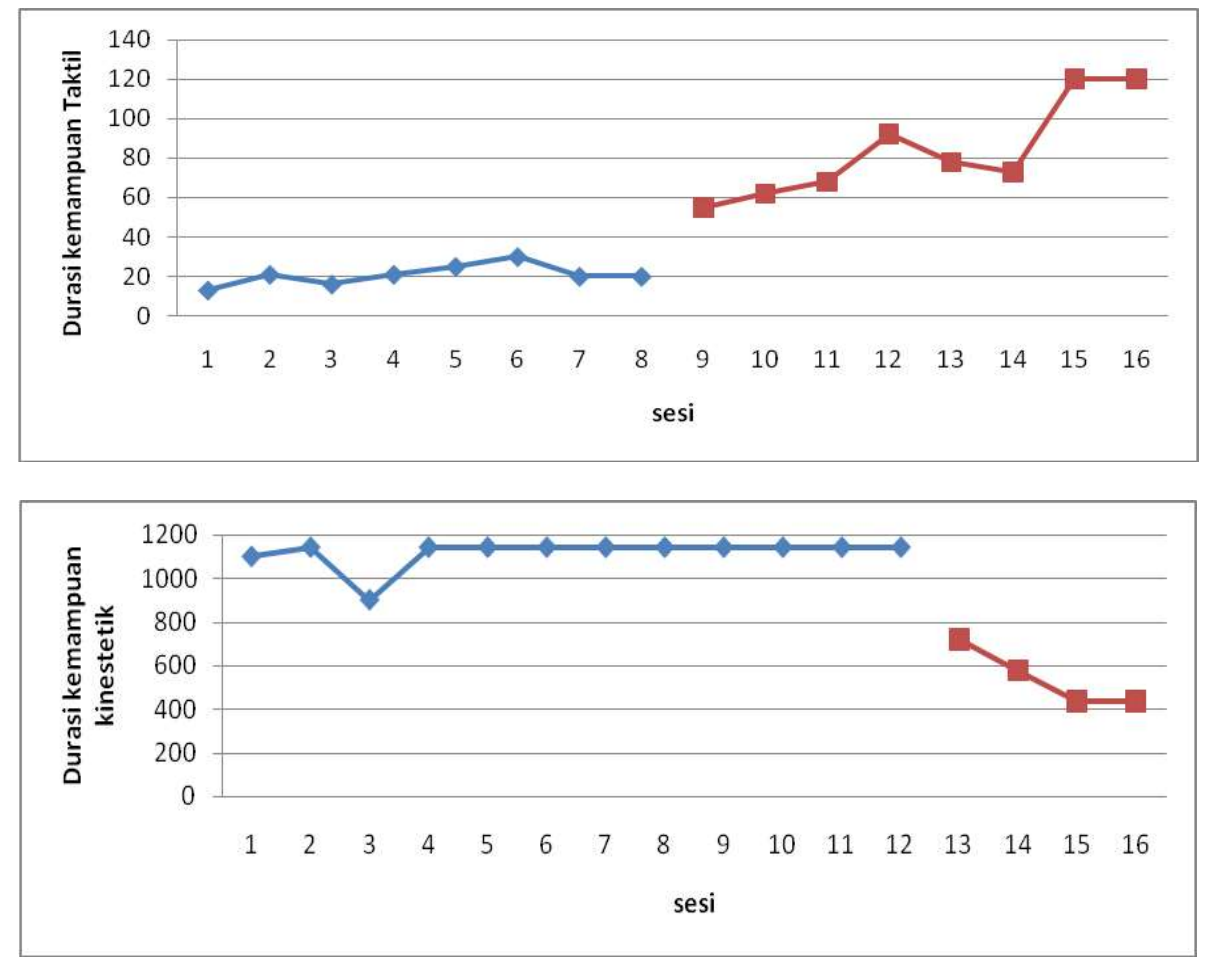

baseline (A) kemampuan taktil dan kinestetik masih terus dilakukan, setelah intervensi (B) pada kemampuan vestibular pada empat sesi awal sudah dalam kondisi stabil maka intervensi (B) sudah dapat dilakukan pada kemampuan taktil, sementara itu fase baseline (A) terus dilakukan sampai intervensi (B) kemampuan taktil pada delapan sesi awal sudah berada pada kondisi stabil maka intervensi (B) untuk kemampuan kinestetik bisa dilakukan.

Dari grafik 11. juga terlihat hanya ada satu treatmen atau intervensi yang dilakukan dimana intervensi tersebut mempengaruhi beberapa target behavior akan tetapi target behavior tersebut tidak terikat (independent) sehingga dapat terlihat efek dari intervensi terhadap target behavior. Oleh karena itu, latihan sensorimotor dapat memberikan pengaruh yang positif terhadap peningkatan kemampuan vestibular (kemampuan mempertahankan posisi kepala dan tubuh), kemampuan taktil (kemampuan mempertahankan stabilitas tangan kiri untuk memegang pinggiran kertas saat menulis), dan kemampuan kinestetik (keluwesan jari dan tangan yang dilihat dari waktu yang dibutuhkan untuk menuliskan sebuah paragraf) subyek.

\section{Kemampuan Propioseptif/Penekanan Alat} Tulis

Tabel 8. Hasil Skor pada Baseline 1 (A1)

\begin{tabular}{|c|c|c|c|c|}
\hline \multirow{2}{*}{ Variabel } & \multicolumn{4}{|c|}{ Fase Baseline 1 (A1) } \\
\cline { 2 - 5 } & 1 & 2 & 3 & 4 \\
\hline $\begin{array}{c}\text { Kemampuan } \\
\text { propioseptif } \\
\text { (penekanan } \\
\text { alat tulis) }\end{array}$ & $14 \%$ & $12 \%$ & $15,3 \%$ & $15,3 \%$ \\
\hline
\end{tabular}

Berdasarkan tabel 8. nilai yang diperoleh subyek pada sesi pertama adalah $14 \%$, pada sesi kedua adalah $12 \%$ sedangkan pada sesi ketiga dan keempat adalah sebesar 15,3\%. Sedangkan dilihat berdasarkan kecenderungan arah grafik keempat sesi tersebut secara umum mendatar, sedangkan menurut trend stability angka yang diperoleh sebesar $75 \%$ artinya stabilitas perkembangan kemampuan awal subyek dalam aspek propioseptif berada pada tingkat variabel menuju stabil. Nilai persentase subyek yang diperoleh saat melakukan kegiatan menulis berupa menuliskan paragraf yang terdiri dari 150 huruf dengan tidak menembus kertas masih sangat minim. Untuk itu perlu dilanjutkan pada tahap selanjutnya yaitu tahap intervensi. Yang akan dipaparkan seperti di bawah ini. 
Tabel 9. Hasil Skor pada Intervensi (B)

\begin{tabular}{|c|c|c|c|c|c|c|c|c|}
\hline \multirow{2}{*}{ Variabel } & \multicolumn{7}{|c|}{ Fase Intervensi (B) } \\
\cline { 2 - 9 } & 1 & 2 & 3 & 4 & 5 & 6 & 7 & 8 \\
\hline $\begin{array}{c}\text { Kemampuan } \\
\text { propioseptif } \\
\text { (penekanan } \\
\text { alat tulis) }\end{array}$ & $23,3 \%$ & $29,3 \%$ & $34 \%$ & $37,3 \%$ & $39,3 \%$ & $42,7 \%$ & $48,7 \%$ & $49,3 \%$ \\
\hline
\end{tabular}

Ditinjau berdasarkan estimasi kecenderungan arah garfik kedelapan sesi tersebut secara umum meningkat dan menurut perhitungan trend stability perolehan yang didapat oleh subyek sebesar $63 \%$. Artinya tingkat kemampuan propioseptif subyek dalam penekanan alat tulis berada pada tahap variabel menuju stabil. Karena kriteria yang didapat apabila data mengalami kestabilan berkisar $85 \%$ sampai $90 \%$.

Dari data baseline 2 dapat diketahui kecenderungan arah grafik dari keempat sesi tersebut adalah menurun, sedangkan menurut perhitungan trend stability diperoleh nilai $25 \%$

Tabel 10. Hasil Skor pada Baseline 2 (A2)

\begin{tabular}{|c|c|c|c|c|}
\hline \multirow{2}{*}{ Variabel } & \multicolumn{4}{|c|}{ Fase Baseline 2 (A2) } \\
\cline { 2 - 5 } & 1 & 2 & 3 & 4 \\
\hline $\begin{array}{c}\text { Kemampuan } \\
\text { propioseptif } \\
\text { (penekanan } \\
\text { alat tulis) }\end{array}$ & $46,7 \%$ & $33,3 \%$ & $33,3 \%$ & $33,3 \%$ \\
\hline
\end{tabular}

artinya kemampuan subyek dalam propioseptif berada pada tingkat variabel (tidak stabil).

Pada grafik 12 menunjukkan, jika dibandingkan dengan fase baseline 1 , kemampuan subyek dalam menekan alat tulis pada baseline 2 ini mengalami peningkatan. Pada fase baseline 1 itu sendiri nilai yang diperoleh dari sesi kesatu sampai pada sesi keempat berada pada rentang $12 \%$ $15,3 \%$.

Pada tahap pelaksanaan intervensi nilai persentase tertinggi yang dicapai subyek adalah $49,3 \%$ pada sesi ke 3 dan nilai terkecil yang diperoleh subyek pada tahap intervensi ini adalah $23,3 \%$ yang terjadi pada sesi ke 1 . Pengukuran pada tahap baseline 2 dilakukan sama seperti pada baseline 1 yaitu subyek tidak lagi diberikan intervensi akan tetapi subyek langsung dihadapkan pada kegiatan menulis berupa menuliskan paragraf yang terdiri dari 150 huruf dengan tidak tembus ke belakang kertas dan hasil persentase tertinggi yang dicapai oleh subyek adalah $46,7 \%$ pada sesi ke-1 sampai pada sesi ke-4 dan nilai yang terkecil yang didapatkan oleh subyek adalah 33,3\% pada sesi ke-2 sampai pada sesi ke-4. Adapun perbandingan mean level pada desain A - B - A dapat dilihat pada tabel 10. dan grafik 13 . berikut ini.

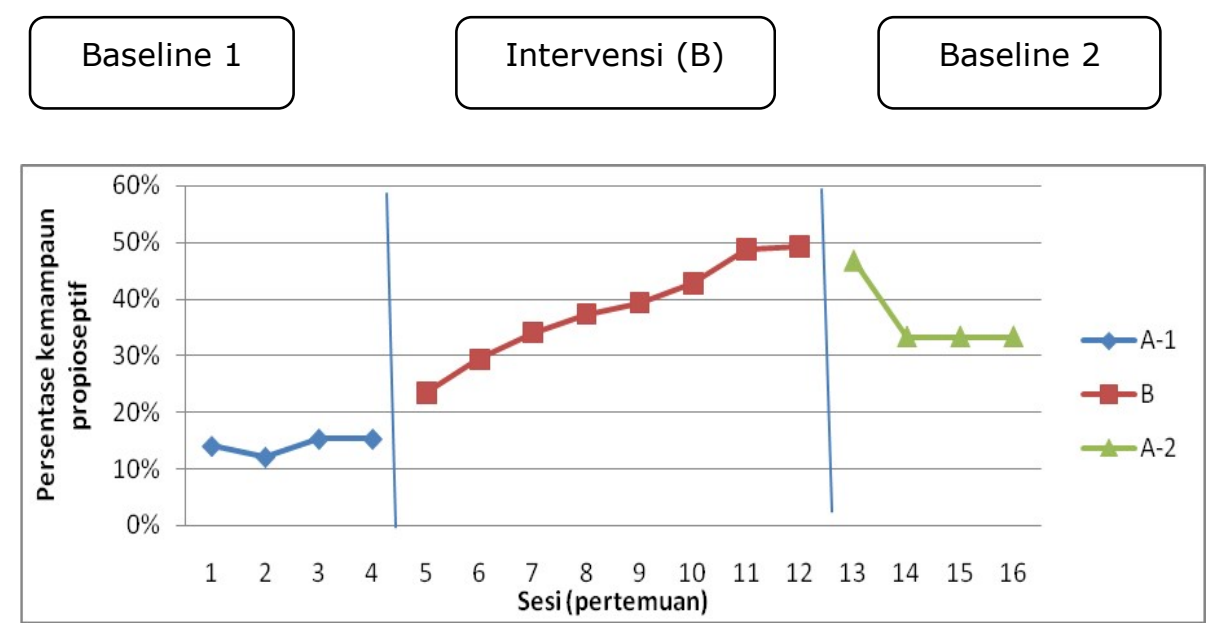

Grafik 12. Analisis perhitungan persentase kemampuan propioseptif anak Autistic Spectrum Disorder (ASD) dan mean level pada tahap A1, B, A2 
Tabel 13. Perkembangan Kemampuan Propioseptif (Mean Level A-B-A Design)

\begin{tabular}{|c|c|c|c|c|c|c|}
\hline $\begin{array}{c}\text { Inisial } \\
\text { siswa }\end{array}$ & $X(A-1)$ & $X(B)$ & $X(A-2)$ & $X(B)-X(A-1)$ & $X(B)-X(A-2)$ & $X(A-2)-X(A-1)$ \\
\hline AFZ & $14,2 \%$ & $38 \%$ & $37 \%$ & $23,8 \%$ & $1 \%$ & $22,8 \%$ \\
\hline
\end{tabular}

Keterangan :

\begin{tabular}{|c|c|}
\hline ) & $\begin{array}{l}\text { : Rerata kemampuan propiosep } \\
\text { sebelum intervensi }\end{array}$ \\
\hline$X(B)$ & npuan propioseptif \\
\hline$x(A-2)$ & $\begin{array}{l}\text { mpuan propioseptif } \\
\text { ensi }\end{array}$ \\
\hline$x(B)-X(A-1)$ & $\begin{array}{l}\text { Selisih rerata antara fase inter- } \\
\text { vensi dengan fase baseline } 1\end{array}$ \\
\hline$x(B)-X(A-2):$ & $\begin{array}{l}\text { Selisih rerata antara fase inter- } \\
\text { vensi dengan fase baseline } 2\end{array}$ \\
\hline$(A-1)$ & $\begin{array}{l}\text { : Selisih rerata antara fase baselir } \\
2 \text { dengan fase baseline } 1\end{array}$ \\
\hline
\end{tabular}

Pada tabel 13 Menunjukkan perbedaan mean level antara baseline 1 dengan baseline 2 sebesar $22,8 \%$. Artinya media intervensi dengan menggunakan latihan sensorimotor ini memiliki kontribusi dalam meningkatkan kemampuan propioseptif (penekanan alat tulis) subyek sebesar $22,8 \%$.

Berdasarkan grafik 13 Memperlihatkan bahwa terjadinya perubahan kemampuan subyek dalam aspek propioseptif (penekanan alat tulis) melalui kegiatan menuliskan paragraf yang terdiri dari 150 huruf dengan tidak menembus kertas sebelum dan sesudah dilakukannya intervensi.
Pada fase baseline 1 kemampuan awal subyek dalam propioseptif sebelum diintervensi mendapatkan perolehan nilai sebesar $14,2 \%$, sementara pada saat diberikan intervensi ratarata kemampuan propioseptif subyek meningkat menjadi $38 \%$ dan pada fase baseline 2 kemampuan subyek dalam propioseptif menurun menjadi 37\%. Akan tetapi fakta menunjukkan jika dibandingkan dengan baseline 1 maka nilai tersebut menandakan adanya peningkatan sebelum mendapatkan perlakuan. Dengan demikian dapat dinyatakan bahwa penggunaan latihan sensorimotor dapat memberikan pengaruh yang signifikan dan dapat meningkatkan kemampuan subyek dalam aspek propioseptif (penekanan alat tulis) ketika melakukan aktivitas menulis.

Berdasarkan hasil penelitian dapat digambarkan sebagai berikut:

Pertama, kemampuan vestibular dalam penelitian ini yang akan diukur adalah kemampuan subyek dalam mempertahankan posisi kepala dan tubuh saat melakukan aktivitas menulis dengan pemberian latihan sensorimotor berupa variasi posisi dengan menggunakan bola gymnasium. Berdasarkan hasil analisis data pada kemampuan vestibular terlihat bahwa subyek mengalami

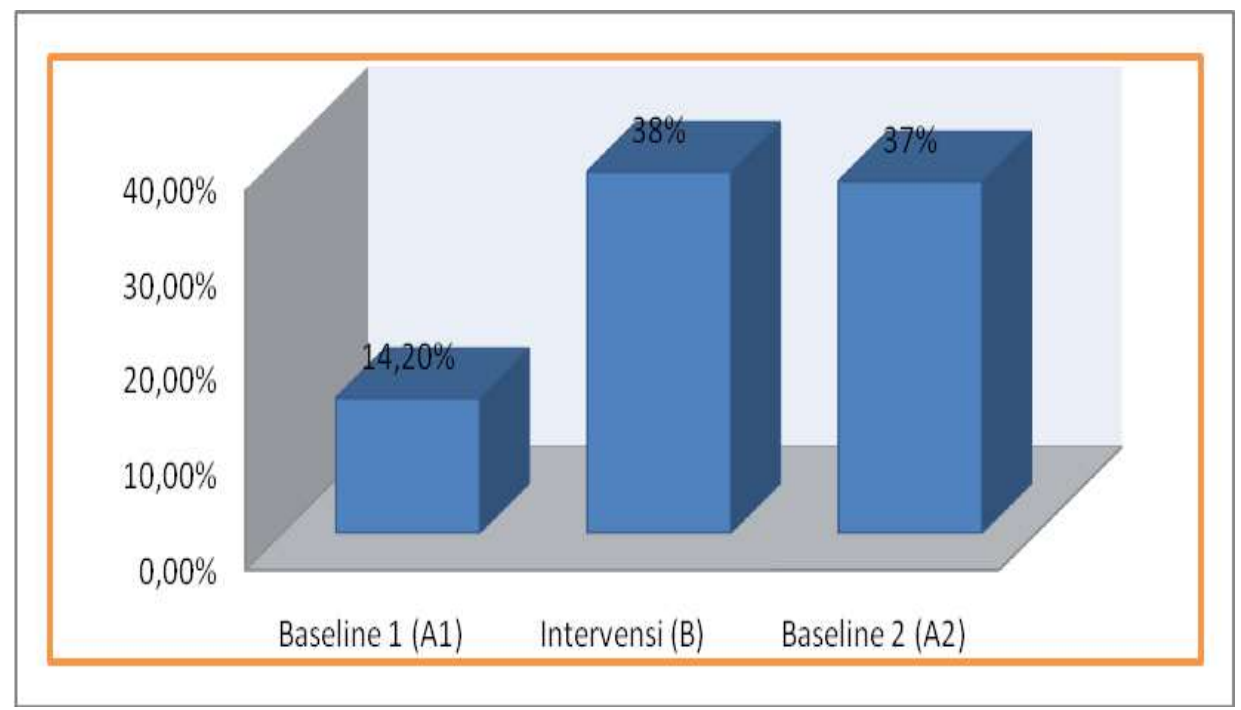

Grafik 13. Perbandingan rata-rata (Mean level) Tahap A - B - A 
peningkatan kemampuan vestibular, hal ini dapat terlihat dari kecenderungan arah dimana kecenderungan arah pada fase baseline (A) cenderung mendatar tetapi pada fase intervensi (B) kecenderungan arah menjadi menaik. Pada perubahan level antara kondisi juga terlihat bahwa sesi terakhir pada fase baseline $(A)$ dengan sesi awal pada fase intervensi (B) terdapat selisih +20 hal ini dapat dikatakan bahwa telah terjadi peningkatan kemampuan sebelum intervensi dan selama intervensi.

Kedua, kemampuan taktil yang akan diukur pada penelitian ini adalah kemampuan subyek untuk mempertahankan stabilitas tangan kiri untuk memegang pinggiran kertas pada saat menulis dengan pemberian latihan sensorimotor berupa manipulasi bola basket. Berdasarkan data hasil penelitian kemampuan taktil subyek menjadi lebih baik dibandingkan pada fase baseline. Hal ini dapat dilihat dari kecenderungan arah dan perubahan data antar kondisi yang cenderung menaik kearah yang lebih positif.

Ketiga, Kemampuan kinestetik yang akan diukur adalah waktu/durasi yang dibutuhkan subyek untuk menuliskan sebuah paragraf dengan pemberian latihan sensorimotor berupa meremas bola karet. Berdasarkan data hasil penelitian terlihat bahwa waktu yang dibutuhkan subyek untuk menuliskan sebuah paragraf menurun, hal ini dapat terlihat dari kecenderungan arah dan perubahan data antar kondisi terlihat menurun kearah yang lebih positif sesuai dengan tujuan intervensi. Begitu pula pada grafik 10 mean yang diperoleh subyek pada fase baseline (A) adalah 1118 sedangkan pada fase intervensi (B) subyek mendapatkan mean sebesar 543 . Hal ini menunjukkan bahwa latihan sensorimotor juga berpengaruh positif terhadap peningkatan kemampuan kinestetik subyek.

Keempat, kemampuan propioseptif yang akan diukur adalah kemampuan subyek dalam menuliskan paragraf yang terdiri dari 150 huruf dengan tidak menembus kertas. Dalam hal ini peneliti menggunakan disain A - B - A dengan satuan ukur persentase, yang dalam pelaksanaannya peneliti melakukan penelitian sebanyak 16 kali pertemuan (sesi) yang terbagi menjadi 4 kali pertemuan untuk baseline 1, 8 kali pertemuan untuk pelaksanaan intervensi dan 4 kali per- temuan untuk baseline 2. Pada fase baseline 1 (A1), persentase nilai keseluruhan yang diperoleh subyek adalah sebesar $56,6 \%$ dan dilihat dari perhitungan trend stability, nilai tersebut menunjukkan nilai variabel/tidak stabil karena nilai yang diperoleh sebesar $75 \%$. Namun peneliti menetapkan untuk melanjutkan pada pemberian intervensi karena dilihat dari angka persentase perolehan skor pada sesi ketiga dan keempat didapatkan angka yang tetap yaitu sebesar $15,3 \%$. Pada pelaksanaan intervensi, peneliti memberikan latihan sensorimotor berupa melempar bola kearah balok dengan tepat untuk membantu meningkatkan hasil tulisan subyek dan hasilnya perolehan persentase nilai subyek secara keseluruhan dapat dikatakan meningkat dari sebelumnya, nilai yang diperoleh subyek adalah $303,9 \%$. Pada fase intervensi ini pun nilai stabilitas yang diperoleh menunjukkan nilai variabel/tidak stabil karena skor trend stability yang didapatkan subyek sebesar $63 \%$. Sedangkan pada fase baseline 2 (A2), persentase nilai keseluruhan yang diperoleh subyek sebesar $146,6 \%$ dan nilai tersebut jika dibandingkan dengan fase baseline 1 (A1) sebelum diberikannya intervensi dapat dikatakan meningkat. Walaupun nilai trend stability yang diperoleh subyek berada pada tingkat variabel (tidak stabil) karena perolehan nilainya berada dibawah $85 \%$ yakni sebesar $25 \%$.

Dilihat dari grafik 14 perbandingan persentase nilai mean level yang diperoleh subyek pada fase baseline 1 (A1), fase intervensi (B) dan fase baseline 2 (A2) terjadi kenaikan dan penurunan. Seperti pada fase baseline 1 ke intervensi perolehan nilai mean level yang didapatkan oleh subyek sebesar $23,8 \%$ nilai tersebut dapat dikatakan meningkat, sedangkan dari fase intervensi ke baseline 2 perolehan nilai mean level yang didapatkan subyek menurun karena skor yang didapatkan sebesar $1 \%$. Akan tetapi jika perolehan nilai mean level pada fase baseline 1 dibandingkan dengan baseline 2 tentu nilai tersebut menunjukkan adanya peningkatan, karena skor yang didapatkan adalah sebesar $22,8 \%$.

Untuk itu dapat disimpulkan bahwa kemampuan subyek untuk menuliskan sebuah paragraf yang terdiri dari 150 huruf dengan tidak me- 
nembus kertas dapat dikatakan sudah jauh lebih baik dari sebelumnya, walaupun pada fase baseline 1, fase intervensi, dan fase baseline 2 belum mencapai kestabilan artinya peningkatan kemampuan menulis subyek dengan menggunakan latihan sensorimotor ini masih memerlukan waktu yang lama supaya dapat mencapai perubahan yang konstan dan dapat memberikan dampak yang lebih positif bagi perkembangan motorik khususnya menulis anak Autistic Spectrum Disorder (ASD).

Berdasarkan hasil analisis dari pengolahan data yang telah dilakukan dan disajikan dalam bentuk grafik garis maupun batang dengan menggunakan disain multiple baseline cross variable untuk target behavior kemampuan mempertahankan posisi kepala dan tubuh (vestibular), stabilitas tangan kiri (taktil), serta keluwesan jari dan tangan (kinestetik), maupun dengan menggunakan disain A - B - A untuk target behavior penekanan alat tullis (propioseptif), maka penerapan latihan sensorimotor ini telah memberikan efek yang positif terhadap peningkatan kemampuan menulis pada anak Autistic Spectrum Disorder (ASD

\section{Simpulan dan Saran Simpulan}

Berdasarkan hasil analisis dari keseluruhan data yang diperoleh dari lapangan, baik itu tingkat kemampuan vestibular, taktil, kinestetik dan propioseptif anak Autistic Spectrum Disorder (ASD) yang berinisial AFZ sebelum maupun setelah intervensi, serta pengaruh latihan sensorimotor terhadap kemampuan menulis dan hasil menulis anak ASD juga dilihat dari beberapa kali pengamatan terlihat adanya kemajuan kearah yang lebih positif. Hal tersebut bisa dilihat dari indikasi-indikasi sebagai berikut. Pertama, aspek kemampuan vestibular subyek dalam hal ini, mampu mempertahankan posisi kepala dan tubuh pada saat melakukan aktivitas menulis, mengarah kearah yang lebih baikKedua, aspek kemampuan taktil subyek dalam hal ini, dapat meningkatkan durasi stabilitas tangan kirinya untuk memegang pinggiran kertas saat menulis, taktil subyek mengalami peningkatan walaupun terkadang masih harus diingatkan. Ketiga, aspek kemampuan kinestetik dalam hal ini, waktu yang dibutuhkan subyek untuk menuliskan sebuah paragraf tidak lagi dalam waktu 30 menit, tetapi subyek dapat meminimalisir waktu yang dibutuhkannya untuk menulis sebuah paragraf rata-rata menjadi 10 menit. Keempat, aspek kemampuan propioseptif dalam hal ini kaitannya dengan penekanan alat tulis mengarah kearah yang lebih baik. Oleh karena itu latihan sensorimotor masih memerlukan waktu yang cukup lama dalam prosesnya. Berdasarkan indikasi-indikasi tersebut, maka disimpulkan bahwa latihan sensorimotor dapat meningkatkan kemampuan menulis AFZ (anak Autistic Spectrum Disorder).

\section{Saran}

Berdasarkan kesimpulan tersebut maka peneliti menyarankan penelitian ini kepada pihak-pihak yang dipandang perlu untuk menindak lanjuti dari hasil penelitian ini. Sehubungan dengan hasil penelitian ini bahwa latihan sensorimotor memiliki pengaruh positif terhadap kemampuan vestibular (kemampuan mempertahankan posisi kepala dan tubuh), taktil (kemampuan memnpertahankan stabilitas tangan kiri), kinestetik (keluwesan jari dan tangan) dan propioseptif (penekanan alat tulis) yang berkaitan dengan kemampuan menulis anak Autistic Spectrum Disorder (ASD). Oleh karena itu peneliti menyarankan beberapa hal diantaranya: 1) Dalam pembelajaran untuk meningkatkan kemampuan menulis dengan latihan sensorimotor, guru diharapkan dapat mengetahui jenis-jenis kegiatan sensorimotor yang sesuai dengan tingkatan usia dan kemampuan anak; dan 2) Untuk mengetahui kemampuan sensorimotor dilakukan assesmen sensorimotor terlebih dahulu dengan menggunakan format assesmen sensorimotor salah satunya yang disusun oleh Lynn A.BalzerMartin, PhD.,O.T.R 


\section{Pustaka Acuan}

Abdurrahman, M. 2003. Pendidikan Bagi Anak berkesulitan Belajar. Jakarta: Rineka Cipta.

Astati, 2001, Pendidikan Anak Autis (Makalah) dalam Seminar Pendidikan Anak Autis, Jurusan PLB FIP UPI)

Attwood, T. 2007. Sindrom Asperger. Jakarta: Dian Rakyat.

Dwi-Hiremawati, A. 2007. Penerapan Latihan Sensorimotor dalam Meningkatkan Kemampuan Menulis pada Anak Berkesulitan Belajar di Klinik Tanaya Bandung. Skripsi pada FIP UPI Bandung: Tidak diterbitkan.

Hiremawati, Anik D., 2007, Penerapan Latihan Sensori Motor dalam meningkatkan Kemampuan Menulis Anak Berkesulitan Belajar (Skripsi, Tidak diterbitkan).

Lerner. J. W.1985. Learning Disabilities: Theories, diagnosis. Adn Teaching Strategies, New Jerse: Houghton Mifflin Company.

Loree. 1970. Psychology of Education, New York: The Ronald Press

Masra, Ferizal. 2008. Autisme : Gangguan Perkembangan Anak. Jakarta: Tempo.

Manjiviona dan Prior,1995, Comparation of Asperger Syndrome and High Functioning Autism on Test of Motor Development. Jurnal of Autism and Developmental Disorders 25(1)- 23-29.

Markam. Soemarmo (1989). Pengenalan Kesulitan Belajar dan DMO, Jakarta: FKUI

Puspita, D. 2002, Membimbing Anak Autis dirumah (Makalah), Disampaikan dalam diskusi forum pemerhati autis.

Rimland. 1990. Teaching Children with Autism: Strategies for Enhance Communication, Autism Research Review 4, Dimethylglycine (DMG), NY:

Russell dan Wanda. 1986. Autism an Executive Disorders, Oxford: Oxford University Press.

Sanders, 1982. The Key to Understanding Meaningful, Perception and Autistic Perseption, University of Nort Carolin.

Saputra Y, 2005. Penerapan Gerak Tari Kijang pada anak autis (skripsi, tidak diterbitkan)

Sufia K, 2009. Memperkenalkan Anak Autis (Makalah), diskusi pemerhati autis

Sherill, 1984. Teaching Children with Autism Through Taks Variationin Physical, New York.

Sugiyono. 2006. Metode Penelitian Pendidikan Pendekatan Kuantitatif dan Kualitatif, dan $R \& D$.

Bandung: Alfabeta.

Sunanto, J., Takeuchi, Koji, dan Nakata, Hideo, 2006. Pengantar Penelitian Dengan Subyek Tunggal, CRICED, University of Tsukuba.

Sunardi dan Sunaryo. 2006. Intervensi Dini Anak Berkebutuhan Khusus, Dikti, Jakarta

Veskarisyanti, A. 2008. 12 Terapi Autis. Yogyakarta: Pustaka Anggrek.

www.idai.com

William, Chris. dan Wright, Barry. 2007. How to Live With Autism and Asperger Syndrom. Jakarta: Dian Rakyat. 